\title{
The 80th Birthday of Muriel Robertson
}

Muriel Robertson is a woman remarkable for many things: her research in littleexplored fields and her capacity to size up problems; her encyclopaedic knowledge not only of biology but of the arts; her zest in life and her prodigious memory for things and people; her generous enthusiasm, occasionally interlarded with rather vehement criticism, for the work of others. She graduated M.A. from the University of Glasgow in 1905, and early showed her mettle by departing unchaperoned to Ceylon with a Carnegie Fellowship to study the life cycle of trypanosomes and other blood parasites in tortoises and leeches. On her return she became assistant to Professor M. A. Minchin at the Lister Institute, but in 1911, at the instigation of Sir Charles Martin, she was appointed Protozoologist to the Protectorate of Uganda under the Colonial Office. There she worked out the life cycle of Trypanosoma gambiense in the tsetse fly by elegant cytological work, and also investigated some aspects of trypanosomiasis in cattle in the field; but a bald statement of scientific work does scant justice to the phenomenon of a young woman bicycling through jungle, armed with her exquisite embroidery and a rifle for crocodiles, discoursing the while in Luganda to her assistants.

In the summer of 1914 Muriel Robertson returned to the Lister Institute and became actively involved in the remarkable collaborative work of British and French laboratories on the bacteriology of gas gangrene. She was Secretary of the first Anaerobes committee set up by the Medical Research Committee, and subsequently wrote the chapters on spore-bearing anaerobes in the Official Military Medical History and in the M.R.C. 'System of Bacteriology'. After further work on anaerobes she resumed work in 1930 on various aspects of protozoa, particularly with a classic description of the reactions of Tetrahymena to antisera, and in the 1939-45 war collaborated with Dr W. R. Kerr in investigations of trichomoniasis causing abortion in cattle. She was elected F.R.S. in 1947, and long after her official retirement continues her bench work indomitably.

On her 80th birthday, 8 April 1963, Muriel Robertson delivered the Marjory Stephenson Memorial Lecture of the Society, a fitting climax to her life-long interest in microbiology. She had had few formal students, but the many workers of all disciplines who have sat at her feet salute on her birthday one perennially young in outlook. 

Journal of General Microbiology, Vol. 33, No. 2

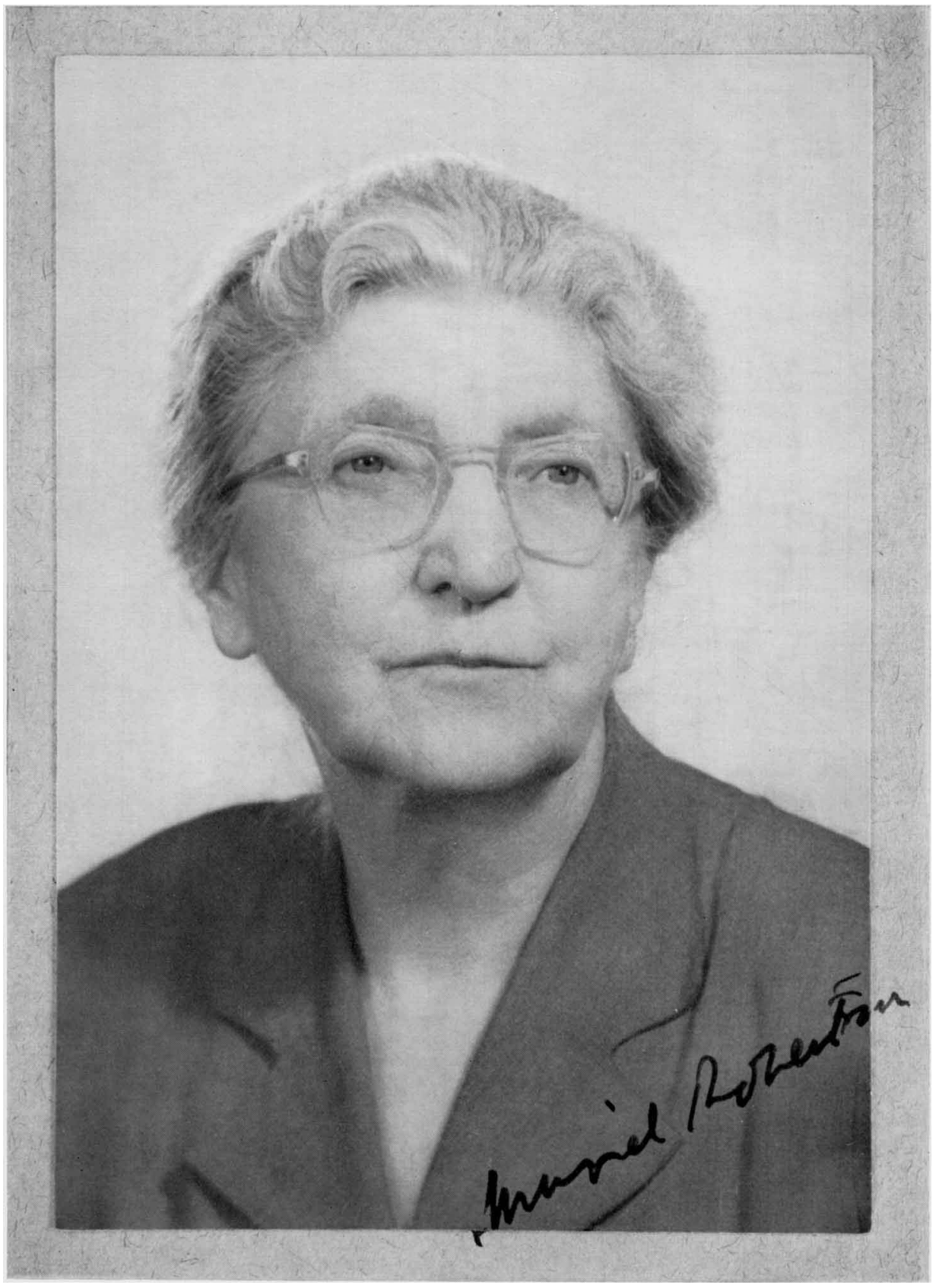

MURIEL ROBERTSON 